\title{
Exchange Rate Volatility and Trade Flows: Evidence from China, Pakistan and India
}

\author{
Sarfaraz Ahmed Shaikh ${ }^{1} \&$ Ouyang Hongbing ${ }^{1}$ \\ ${ }^{1}$ School of Economics, Huazhong University of Science and Technology (HUST),Wuhan, P.R. China \\ Correspondence: Sarfaraz Ahmed Shaikh, School of Economics, Huazhong University of Science and \\ Technology (HUST), Wuhan, P.R. China Tel: 86-130-7277-9585. E-mail: sarfaraz@ hust.edu.cn
}

Received: July 27, 2015

doi:10.5539/ijef.v7n11p121
Accepted: August 27, 2015

Online Published: October 25, 2015

URL: http://dx.doi.org/10.5539/ijef.v7n11p121

\begin{abstract}
This study examines the impact of exchange rate fluctuations on trade flows in case of China, Pakistan and India by using the time series data from 1980 to 2013. Most of the researchers have advocated that exchange rate volatility is negatively associated with general level of trade. In this study we have used the standard deviation of the moving average of the logarithm of the exchange rate as a proxy for volatility. And to investigate this relationship, we have applied the Autoregressive Distributive Lag (ARDL) approach for co-integration which estimates the short and long run relationship among the variables for the said period. The results of this empirical work have suggested that exchange rate volatility is negatively associated with Chinese exports in short run while positively associated in long run. However, in the case of Pakistan and India both in the short run and long run, the exchange rate volatility is negatively associated with total volume of trade.
\end{abstract}

Keywords: exchange rate volatility, exports, trade, Autoregressive Distributive Lag (ARDL)

\section{Introduction}

It is a baffling dilemma that exchange rate volatility really affects the trade. A lot of empirical studies have already been conducted on the topic. However the results are surprisingly mixed. So the debate is open for the researches. However, it varies from country to country and how much the economy of the country is developed? These different viewpoints have also been supported by the empirical literature resulting to a mixed support with regard to the effects of exchange rate fluctuation on trade. Motivated by the lack of extensive literature for these rapidly growing Asian economies, the purpose of this research is to examine whether there is any significant relationship between exchange rate volatility and exports in case of China, Pakistan and India. And also to present a new complexity to the issue in hand through the examination of a relationship in short runs as well as long run.

Pakistan and India are emerging open economies which depend on imports to meet the demand of consumer and capital goods and still operate beneath the full employment. Since 1982, in most of the developing economies like Pakistan the local currency always used to depreciate under flexible exchange rates regimes since 1982 (Choudhri \& Hakura, 2001). And this depreciation leads to major increase in the price levels and inflation rate, which directly or indirectly affects the trade. The aim of monetary policy in developing countries is to promote economic growth and to stabilize the value of the currency. Therefore the exchange rate passes through to the domestic wholesale as well as consumer prices and also is a vital link while formulating the monetary policy.

Pakistan an open economy, but still domestic prices cannot remain unaffected by the external price shocks. These external price shocks can be exchange rate appreciation or depreciation and any change in the import prices. The increase or decrease in the currency exchange rate will result in the change of price level of imported refined goods and imported inputs which are used as the intermediary goods and that definitely changes the cost of finished goods and services in the country (Janjua, 2007).

China has very few such opportunities to control exchange rate volatility as compared to the developed economies. An increase in the volatility results in the increased exchange rate risk, which must be controlled by the hedging instruments. Chinese Authorities have maintained the exchange rate stability and effectiveness of monetary policy on the cost of free international mobility of capital (Nishimura \& Hirayama, 2013). Chinese Government had made recent policy changes in 2012. These policy changes are the replica of the many 
developed economies policies, which they implemented in early 70s. The policy changes aimed to make the exchange rate more flexible. For this purpose they retained the independence in their monetary policy but allowed the flexibility in the movement of international capital flows. Therefore china is in-between the developing and developed economies in case of the policy reforms to rationalize more flexible foreign exchange market to facilitate exporters and importers.

The early empirical studies like (Thursby \& Thursby, 1987) typically witnessed large negative effects of exchange rate uncertainty on the foreign trade. (Bredin \& Cotter, 2008) conducted the research on Irish economy and provided robust evidence that there is significant positive relationship between exchange rate volatility and the trade of Ireland with UK and US. (Baum \& Caglayan, 2010) has conducted the empirical study and made an analysis of the bilateral trade in the developed nations and found that out of 143 instances of sample, only 30 instances witnessed, where he found the significant relation between exchange rate volatility and trade.

The less developed economies are more sensitive to the exchange rate volatility in term of its effect on foreign trade. The uncertainty of exchange rate highly affects the trade in the less developed economies because of lower level of financial developments. There are several researches in which they have measured the effect of exchange rate uncertainty on the foreign trade in emerging economies. (Tenreyro, 2007) conducted an in-depth analysis of 87 countries inclusive of both developed and under developed economies. He used the panel data set of these 87 countries and applied gravity model to test the effect. He also controlled the several sources of bias including those that arise from Jensen's inequality as a result of logarithmic transformations. But he couldn't find any significant relation between exchange rate volatility and trade. (Grier \& Smallwood, 2007) conducted study on the both mixed sample of developed and under developed countries. In this study the author found a modest evidence of negative effects of exchange rate uncertainty for exports in case of sample of developing countries only. While in sample set of developed economies, very little evidence of significance was found. The study of (Caglayan, Dahi, \& Demir, 2013) solely focuses on emerging market economies. The authors used the separate dynamic panel data sets to test the bilateral exports among the 28 sample countries. The findings are again very much mixed. There is almost same number of positive links as much as of negative links while analyzing exports from emerging markets to developed economies.

(McKenzie, 1999) concludes that the empirical studies have had "greater success in deriving a statistically significant relationship between volatility and trade". (Calvo \& Reinhart, 2000) also reviewed a set of such studies and reached the similar conclusion that there is a relationship between trade and exchange rate volatility. Some other studies i.e. (Chowdhury, 1993) and (Caporale \& Doroodian, 1994) concluded that there is an adverse consequence of exchange rate volatility on foreign trade. Similarly (Klein, 1990), (McKenzie, 1998), (Bailey, Tavlas, \& Ulan, 1987), (Koray \& Lastrapes, 1989), (Asseery \& Peel, 1991), (Kroner \& Lastrapes, 1993), (McKenzie \& Brooks, 1997), (McKenzie, 1998), (Daly, 1998), (Wei, 1999) and (Chou, 2000) have also witnessed some cases where as increase in exchange rate volatility can have both progressive and adverse implications on foreign trade depending on products as well as countries. There is another study by Aristotelous, which has surprising results. (Aristotelous, 2001) concludes his work and finds that that exchange rate volatility has no any significant impact on the performance of the British trade with United States for the period of 18891999.

Therefore we can say that the conclusions in these researches cannot be perceived as ultimate. The empirical as well as theoretical studies have confirmed again and again that there is an ambiguous nexus between exchange rate volatility and foreign trade.All the previous researches confirm the fact that there are situations in which the exchange rate volatility can have either negative or positive effects on trade. The remainder of this paper is organized as follows. Section 2 is about methodology, then results and discussion are presented in section 3 and finally section four concludes the paper.

\section{Methodology}

Following (Goldstein \& Khan, 1976) empirical analysis, we have developed the model of our study to account for the effects of volatility on exports, whereas we have ignored the seasonal effect in our model because quarterly data is not available for Pakistan and India. Thus we have summarized our model as given below:

$$
\log \left(X_{t}\right)=\lambda_{0}+\lambda_{1} \log \left(P_{X} / P_{W}\right)+\lambda_{2} \log \left(G D P_{t}\right)+\lambda_{3} \log \left(V_{t}\right)+\varepsilon_{t}
$$

Where: $(\mathrm{X})$ is export quantities, (PX/Pw) is relative prices, (GDP) is real world GDP, (V) is volatility and (e) is an error term. Our dependent variable is real export value; therefore, we have used the unit value method to create the real export values. Moreover, the explanatory variables are relative prices, domestic GDP and volatility. 
The relative prices are measured to divide the corresponding sector export price over an index comprised of world export prices, while for competitiveness we have used the proxy of domestic GDP. However the last explanatory variable is volatility, there is no clear way to measure exchange rate volatility however some of the empirical researches suggested to utilized the standard deviation of the moving average of the logarithm of the exchange rate. Having previously worked with such a measure (the standard deviation of the moving average of the logarithm of the exchange rate) it is obvious that there are some benefits from the usage of such a measure. Therefore:

$$
V_{T+m}=\left[\frac{1}{m} \sum_{i=1}^{m}\left(R_{t+1-1}-R_{t+i-2}\right) \times 2\right] \times \frac{1}{2}
$$

Where; $(\mathrm{R})$ is nominal/real effective exchange rate, $(\mathrm{M})$ is the number of years we measure the standard deviation of the moving average of the logarithm of the exchange rate. To estimate the variable of volatility for this purpose, we have calculated the standard deviation of the moving average of the logarithm of the real effective exchange rate. The data of the variables are derived from International Financial Statistics (IFS) for Pakistan. However, all of the variable's data is annually collected from 1970 to 2013.

Before, the selection of any econometric method, it is very important in case of time series data, to conduct stationary analysis of variables. Therefore first we tested the data for unit root. For this purpose, we applied the Augmented Dickey Fuller (ADF) test. Table 01 has reported the results of ADF test which shows that some of the variables are integrated at level while some are integrated at first difference. The variables that are integrated at level are exchange rate volatility in case of China, Pakistan and India, while relative prices in case of China and India are also integrated at level and rest of the variables in case of China, Pakistan and India are stationary at first difference.

After the results of ADF test as shown in table 01, we have selected ARDL as an econometric test. It best fits in the given situation because Autoregressive distributive lag (ARDL) approach has some advantages over other techniques. First, in case of small sample ARDL approach give better results as compared to other traditional approaches. Second, ARDL take sufficient number of lags to general to specific modeling in data greeting process. Third, ARDL approach derived Error Correction Term (ECT), through a simple linear transformation, without losing the long run information, which shows us the speed of adjustment from short run dis-equilibrium to lung run equilibrium. Fourth, ARDL approach is free from correlation of residual, so it solves the problem of endogeneity.

\section{Results and Discussion}

Table 1. Results of ADF test

\begin{tabular}{cccc}
\hline Variables & China & Pakistan & India \\
\hline $\mathrm{X}$ & $\mathrm{I}(1)$ & $\mathrm{I}(1)$ & $\mathrm{I}(1)$ \\
$(\mathrm{Px} / \mathrm{Pw})$ & $\mathrm{I}(0)$ & $\mathrm{I}(1)$ & $\mathrm{I}(0)$ \\
$\mathrm{GDP}$ & $\mathrm{I}(1)$ & $\mathrm{I}(1)$ & $\mathrm{I}(1)$ \\
$\mathrm{V}$ & $\mathrm{I}(0)$ & $\mathrm{I}(0)$ & $\mathrm{I}(0)$ \\
\hline
\end{tabular}

Note. $* * * \mathrm{p}<0.01, * * \mathrm{p}<0.05, * \mathrm{p}<0.10$.

The results of ADF test show that variables in the model are integrated of mixed of $\mathrm{I}(0)$ and $\mathrm{I}(1)$. Therefore, in a given situation the best econometrics technique which we can apply to estimate the short and long run relationship, is ARDL, established by (Hashem \& Shin, 1995) and later extended by (Hashem, Shin, \& Smith, 2001). The ARDL technique is applicable regardless of order of integration and the same time it gives us both short and long-term coefficients of the model. Thus, the ARDL model of our study is as under:

$$
\begin{aligned}
& \Delta \log X_{t}=\lambda_{0}+\sum_{i=0}^{j} \lambda_{1 i} \Delta \log \left(P_{X} / P_{W}\right)_{t-i}+\sum_{i=0}^{j} \lambda_{2 i} \Delta \log (G D P)_{t-i}+\sum_{i=0}^{j} \lambda_{3 i} \Delta \log V_{t-i}+\sum_{i=0}^{j} \lambda_{4 i} \Delta \log X_{t-i} \\
& \left.a_{\left(P_{x} / P_{W}\right.}\right) \log \left(P_{X} / P_{W}\right)_{t-1}+a_{G D P} \log G D P_{t-1}+a_{V} \log V_{t-1}+a_{X} \log X_{t-1}+\varepsilon_{t}
\end{aligned}
$$

Where: the short run multipliers are $\lambda_{1}, \lambda_{2}, \lambda_{3}$ and $\lambda_{4}$ while the long run coefficients are $a_{\left(P_{X} / P_{W}\right)}, \alpha_{G D P}, \alpha_{V}$ and $\alpha_{X}$. Therefore, the null and alternative hypothesis for co-integration is:

$$
H_{0}=\alpha_{\left(P_{X} / P_{W}\right)}=\alpha_{G D P}=\alpha_{V}=\alpha_{X}=0
$$




$$
H_{1}=\alpha_{\left(P_{X} / P_{W}\right)} \neq \alpha_{G D P} \neq \alpha_{V} \neq \alpha_{X} \neq 0
$$

We have applied the bounds test of (M. Hashem Pesaran et al., 2001) to test these hypotheses of co-integration. The bound test critical values at $95 \%$ and $90 \%$ are reported it Table 2 which shows that in cases of China, Pakistan and India the F-statistics calculated are greater than UB values. Therefore, we reject the null hypothesis of no co-integration and accept the alternative hypothesis of existing co-integration. Now we are able to apply the ARDL approach on our data and to estimate the short and long run coefficients of the model.

Table 2. Results of bound test

\begin{tabular}{ccccccc}
\hline \multirow{2}{*}{ Country } & F-statistics & \multicolumn{3}{c}{$95 \%$} & \multicolumn{2}{c}{$90 \%$} \\
\cline { 3 - 6 } & & LB & UB & LB & UB \\
\hline China & 08.21 & 3.27 & 4.30 & 2.67 & 3.57 \\
Pakistan & 12.23 & 2.7254 & 4.2063 & 2.1617 & 2.4397 \\
India & 06.09 & 2.7467 & 4.1590 & 2.1882 & 3.3829 \\
\hline
\end{tabular}

Note. upper bound (UB) and lower bound (LB).

The long run results of ARDL model are reported in Table 03 which shows that all of the variables have correct signs, as well as statistically significant at different level. The coefficients of relative prices are $0.302,0.640$ and 0.403 for China, Pakistan and India respectively which indicates that a one percent increase in relative prices will leads to raise the exports of respective country by $0.302,0.640$ and 0.403 percent respectively. Similarly the coefficients of GDP also carried positive signs which indicate that GDP is positively associated with exports; it indicates that a one percent increase in GDP will augment the exports of China, Pakistan and India by 0.324, 0.202 and 0.300 percent respectively.

Table 3. Results of ARDL in the long run

\begin{tabular}{ccccc}
\hline Country & $(P x / P w)$ & $G D P$ & $V$ & Model \\
\hline China & $0.302^{*}$ & $0.324^{*}$ & 0.011 & ARDL $(1,0,1)$ \\
Pakistan & $0.640^{*}$ & $0.202^{* *}$ & $-0.125^{*}$ & ARDL $(1,0,0)$, \\
India & $0.403^{* *}$ & $0.300^{*}$ & $-0.202^{*}$ & ARDL $(0,1,0)$ \\
\hline
\end{tabular}

Note. ${ }^{* * *} \mathrm{p}<0.01, * * \mathrm{p}<0.05, * \mathrm{p}<0.10$.

Similarly the short run parameters of ARDL model are reported in Table 04. The speed of convergence to equilibrium from disequilibrium is shown by Error Correction Term (ECT). The ECTs of China, Pakistan and India are $-0.11,-0.21$ and -0.14 which are quite high and show a good speed of adjustment from disequilibrium to equilibrium. In the short run relative prices have positive impact of exports in case of China, Pakistan and India likewise real GDP is positively associated with exports in all cases, a one percent rise in real GDP will lead to amplify exports of China, Pakistan and India by $0.521 \%, 0.321 \%$ and $0.291 \%$ respectively. The exchange rate volatility has positive impact on exports of China, Pakistan and India.

Table 4. Results of ARDL in the short run

\begin{tabular}{cccc}
\hline Country & China & Pakistan & India \\
\hline Log (Px/ Pw) & $0.341^{*}$ & $0.421^{* *}$ & $0.231^{* *}$ \\
$\log (\mathrm{GDP})$ & $0.521^{*}$ & $0.321^{*}$ & $0.291^{* *}$ \\
$\log (\mathrm{V})$ & 0.141 & 0.1136 & $0.540^{*}$ \\
ECT $(-1)$ & $-0.1503^{*}$ & $-0.092^{*}$ & $-0.132^{*}$ \\
$\mathrm{R}$ & 0.60 & 0.75 & 0.70 \\
DW & 1.76 & 2.12 & 1.43 \\
F- Stat: & 20.11 & 98.21 & 32.11 \\
$\chi_{\text {LM }}^{2}$ & $2.13(0.30)$ & $0.04(0.95)$ & $09.11(0.01)$ \\
$\chi_{\text {Normality }}^{2}$ & $6.33(0.05)$ & $0.43(0.65)$ & $2.14(0.42)$ \\
$\chi_{\text {Hetro: }}$ & $0.025(0.42)$ & $4.18(0.06)$ & $2.11(0.23)$ \\
\hline
\end{tabular}

Note. $* * * p<0.01, * * p<0.05, * p<0.10$.

Different diagnostic tests were applied to test the reliability of the model. These diagnostic tests are LM test for 
autocorrelation $\left(\chi_{L M}^{2}\right)$, Jerque-Bera test for normality $\left(\chi_{\text {Nomality }}^{2}\right)$ and White test for hetroskedastcity $\left(\chi_{\text {Hetro }}^{2}\right)$. All results of the diagnostic tests indicated that our model is free from econometric problems such as autocorrelation and hetroskedasticity. Moreover we also applied CUSUM and CUSUMsq to test the stability of the parameters. We reported the figures of CUSUM and CUSUMsq at Appendix 01 which shows that the parameters of China, Pakistan and India qualify the test of stability.

\section{Conclusion}

This study applied the ARDL approach to co-integration to estimate the effect of exchange rate volatility on exports over the period 1980 to 2013 in case of China, Pakistan and India. The impact of exchange rate volatility on exports is a debatable issue and different researchers have different point of view. Therefore this is the motivation behind this research. For this research we have followed the empirical analysis by (Goldstein \& Khan, 1976) and have developed the model of our study. The only limitation of this study is that the seasonal effect in our model has been ignored because quarterly data is not available for Pakistan and India.

Our empirical results show that in short run, there is a negative and significant relationship between exchange rate volatility and exports in case of China, Pakistan and India. However, in the long run the exchange rate volatility have positive relationship with china exports but statistical insignificant. Thus on the basis of our results, we have broadly concluded that exchange rate volatility have negative impact on exports for some countries, but not for all countries. The results of this study have an extensive importance for policy makers. We can suggest to policymakers that while applying economic policy, they should consider volatility for some but not for all countries.

\section{References}

Aristotelous, K. (2001). Exchange-rate volatility, exchange-rate regime, and trade volume: Evidence from the UK-US export function (1889-1999). Economics Letters, 72(1), 87-94. http://dx.doi.org/10.1016/S0165-1765(01)00414-1

Asseery, A., \& Peel, D. A. (1991). The effects of exchange rate volatility on exports. Economics Letters, 37(2), 173-177. http://dx.doi.org/10.1016/0165-1765(91)90127-7

Bailey, M. J., Tavlas, G. S., \& Ulan, M. (1987). The impact of exchange-rate volatility on export growth: Some theoretical considerations and empirical results. Journal of Policy Modeling, 9(1), 225-243. http://dx.doi.org/10.1016/0161-8938(87)90010-X

Baum, C. F., \& Caglayan, M. (2010). On the sensitivity of the volume and volatility of bilateral trade flows to exchange rate uncertainty. Journal of International Money and Finance, 29(1), 79-93. http://dx.doi.org/10.1016/j.jimonfin.2008.12.003

Bredin, D. O. N., \& Cotter, J. (2008). Volatility and Irish Exports. Economic Inquiry, 46(4), 540-560. http://dx.doi.org/10.1111/j.1465-7295.2007.00101.x

Caglayan, M., Dahi, O. S., \& Demir, F. (2013). Trade Flows, Exchange Rate Uncertainty, and Financial Depth: Evidence from 28 Emerging Countries. Southern Economic Journal, 79(4), 905-927. http://dx.doi.org/10.4284/0038-4038-2011.174

Calvo, G. A., \& Reinhart, C. M. (2000). Fear of Floating. National Bureau of Economic Research Working Paper Series, No. 7993. http://dx.doi.org/10.3386/w7993

Caporale, T., \& Doroodian, K. (1994). Exchange rate variability and the flow of international trade. Economics Letters, 46(1), 49-54. http://dx.doi.org/10.1016/0165-1765(94)90076-0

Chou, W. L. (2000). Exchange Rate Variability and China's Exports. Journal of Comparative Economics, 28(1), 61-79. http://dx.doi.org/10.1006/jcec.1999.1625

Choudhri, E. U., \& Hakura, D. S. (2001). Exchange Rate Pass-Through to Domestic Prices: Does the Inflationary Environment Matter. IMF Working Paper, 01/194.

Chowdhury, A. R. (1993). Does Exchange Rate Volatility Depress Trade Flows? Evidence from ErrorCorrection Models. The Review of Economics and Statistics, 75(4), 700-706. http://dx.doi.org/10.2307/2110025

Daly, K. (1998). Does exchange rate volatility impede the volume of Japan's bilateral trade? Japan and the World Economy, 10(3), 333-348. http://dx.doi.org/10.1016/S0922-1425(97)00036-4 
Goldstein, M., \& Khan, M. S. (1976). Large versus Small Price Changes and the Demand for Imports. Staff Papers (International Monetary Fund), 23(1), 200-225. http://dx.doi.org/10.2307/3866671

Grier, K. B., \& Smallwood, A. D. (2007). Uncertainty and Export Performance: Evidence from 18 Countries. Journal of Money, Credit and Banking, 39(4), 965-979. http://dx.doi.org/10.1111/j.1538-4616.2007.00053.x

Janjua, M. A. (2007). Pakistan's External Trade: Does Exchange Rate Misalignment Matter for Pakistan? The Lahore Journal of Economics, Special Edition, 125-154.

Klein, M. W. (1990). Sectoral effects of exchange rate volatility on United States exports. Journal of International Money and Finance, 9(3), 299-308. http://dx.doi.org/10.1016/0261-5606(90)90011-N

Koray, F., \& Lastrapes, W. D. (1989). Real Exchange Rate Volatility and U.S. Bilateral Trade: A Var Approach. The Review of Economics and Statistics, 71(4), 708-712. http://dx.doi.org/10.2307/1928117

Kroner, K. F., \& Lastrapes, W. D. (1993). The impact of exchange rate volatility on international trade: Reduced form estimates using the GARCH-in-mean model. Journal of International Money and Finance, 12(3), 298-318. http://dx.doi.org/10.1016/0261-5606(93)90016-5

McKenzie, M. D. (1998). The impact of exchange rate volatility on Australian trade flows. Journal of International Financial Markets, Institutions and Money, 8(1), 21-38. http://dx.doi.org/10.1016/S1042-4431(98)00022-5

McKenzie, M. D. (1999). The Impact of Exchange Rate Volatility on International Trade Flows. Journal of Economic Surveys, 13(1), 71-106. http://dx.doi.org/10.1111/1467-6419.00075

McKenzie, M. D., \& Brooks, R. D. (1997). The impact of exchange rate volatility on German-US trade flows. Journal of International Financial Markets, Institutions and Money, 7(1), 73-87. http://dx.doi.org/10.1016/S1042-4431(97)00012-7

Nishimura, Y., \& Hirayama, K. (2013). Does exchange rate volatility deter Japan-China trade? Evidence from pre- and post-exchange rate reform in China. Japan and the World Economy, 25-26, 90-101. http://dx.doi.org/10.1016/j.japwor.2013.03.002

Pesaran, M. H., \& Shin, Y. (1995). An autoregressive distributed lag modeling approach to cointegration analysis. DAE Working papers (9514).

Pesaran, M. H., Shin, Y., \& Smith, R. J. (2001). Bounds testing approaches to the analysis of level relationships. Journal of Applied Econometrics, 16(3), 289-326. http://dx.doi.org/10.1002/jae.616

Tenreyro, S. (2007). On the trade impact of nominal exchange rate volatility. Journal of Development Economics, 82(2), 485-508. http://dx.doi.org/10.1016/j.jdeveco.2006.03.007

Thursby, J. G., \& Thursby, M. C. (1987). Bilateral Trade Flows, the Linder Hypothesis, and Exchange Risk. The Review of Economics and Statistics, 69(3), 488-495. http://dx.doi.org/10.2307/1925537

Wei, S. J. (1999). Currency hedging and goods trade. European Economic Review, 43(7), 1371-1394. http://dx.doi.org/10.3386/w6742

\section{Appendix A}

Plot of Cumulative Sum of Recursive Residuals

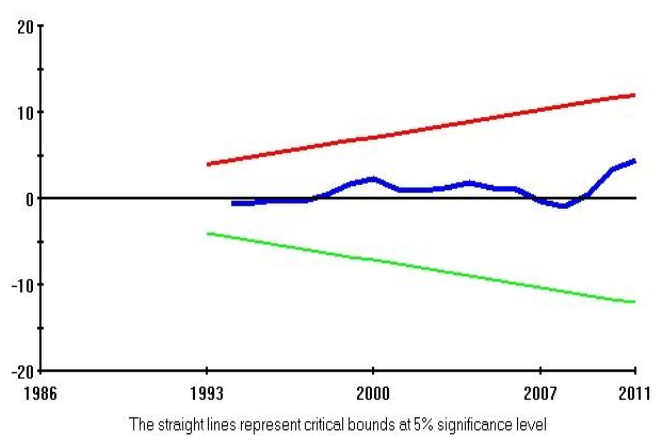

Plot of Cumulative Sum of Squares of Recursive Residuals

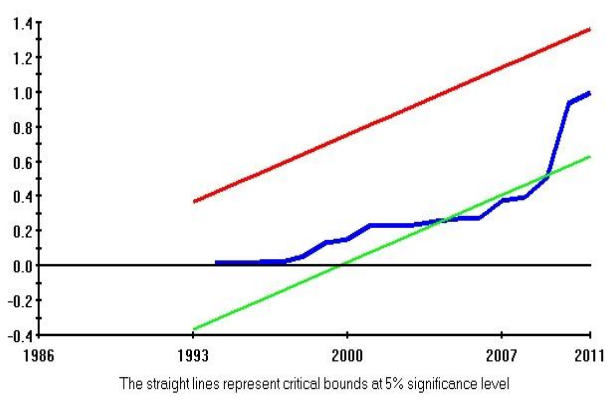

Figure A1. China (plot of recursive residuals) 
Plot of Cumulative Sum of Recursive Residuals

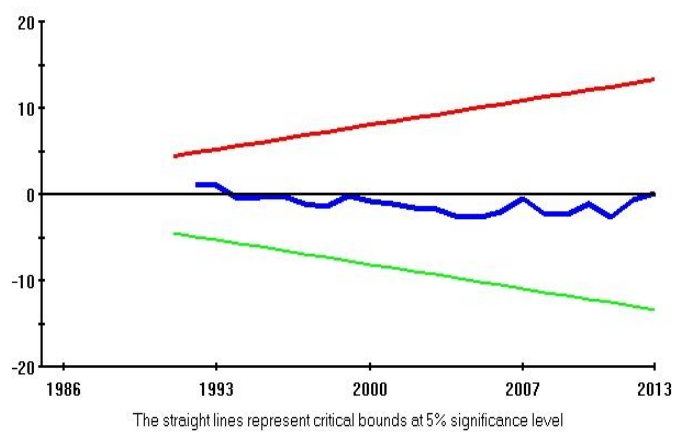

Plot of Cumulative Sum of Squares of Recursive Residuals

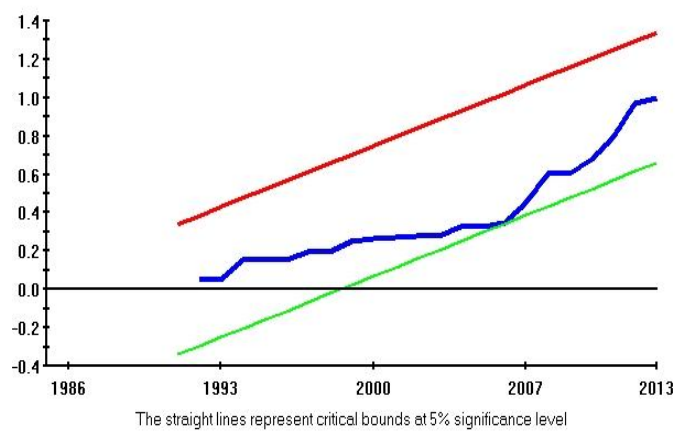

Figure A2. Pakistan (plot of recursive residuals)

Plot of Cumulative Sum of Recursive Residuals

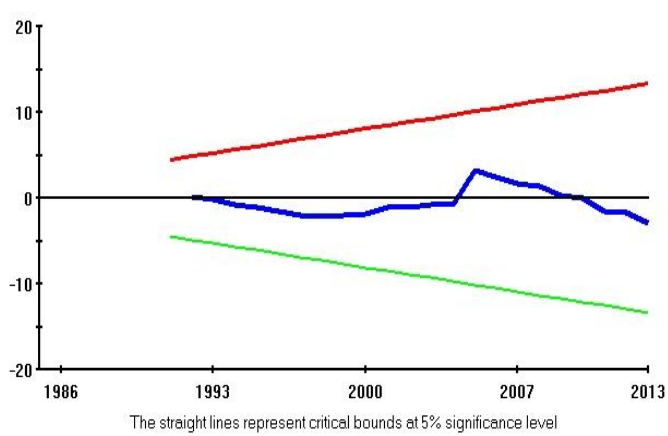

Plot of Cumulative Sum of Squares of Recursive Residuals

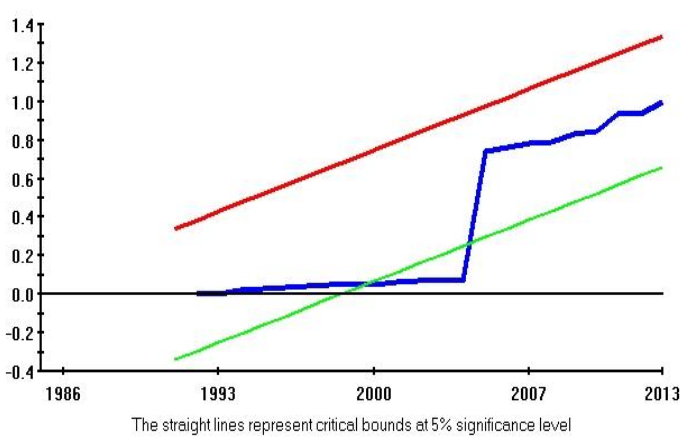

Figure A3. India (plot of recursive residuals)

\section{Copyrights}

Copyright for this article is retained by the author(s), with first publication rights granted to the journal.

This is an open-access article distributed under the terms and conditions of the Creative Commons Attribution license (http://creativecommons.org/licenses/by/3.0/). 